\title{
Penciptaan Teater Tubuh
}

\author{
Tony Supartono \\ InstitutSeni Indonesia Yogyakarta \\ Email : bandungcity66@yahoo.com
}

\begin{abstract}
The process of creative of theatrical body is an offer of renewal theatre by exploring and processing the body, which become the main key in theatre production. This paper proposed the design to offer new thinking, and alternative thinking. Creative of theatrical bodyis a process of body practice with the body consciousness either as an idea or the body itself as the idea, the learning process of the body until get the consciousness movements which resulted by the body. For the process of practice the researcher called it as "Actor Body Interrogation" that is the process of breaking and re-asking the problem of actors' body.

Creative of theatrical body offers new point of view about the body, which not only as the expression media, but the body itself stands alone as its identity. The body is considered as the phenomena which stand alone and also making relationship to the environment, spaces, buildings, vehicles, peoples, even to the society and their ideology which dominant. Therefore, creative of theatricalbody is a process of complete theatre between actor, and the body laugaugeinclude its relationship to the society.
\end{abstract}

Keyword: theatre, body, body interogation, public space

\begin{abstract}
ABSTRAK
Proses penciptaan teater tubuh merupakan penawaran pembaharuan teater dengan menggarap dan mengolah tubuh, yang menjadi kunci utama produksi teater. Paper ini mengajukan rancangan untuk menawarkan pikiran-pikiran baru, pikiran-pikiran alternatif. Penciptaan teater tubuh adalah proses latihan tubuh dengan kesadaran tubuh sebagai gagasan atau tubuh itu sendiri sebagai ide, proses belajar pada tubuh sehingga mendapat kesadaran gerak-gerak yang dilahirkan oleh tubuh. Untuk proses latihannya penulis menamakannya "interogasi tubuh aktor", yaitu proses membongkar dan mempertanyakan kembali persoalan tubuh aktor.

Penciptaan teater tubuh menawarkan pandangan baru tentang tubuh yang bukan sekedar media ungkap tetapi tubuh itu sendiri mandiri sebagai sebuah identitas. Tubuh dipandang sebagai fenomena yang berdiri sendiri tetapi sekaligus melakukan relasi dengan lingkungan: jalan, bangunan, kendaraan, orang-orang dan bahkan seluruh masyarakat dan ideologinya yang sedang dominan. Dengan demikian penciptaan teater tubuh adalah proses teater yang utuh antara aktor dan bahasatubuh sekaligus relasinya dengan masyarakat.
\end{abstract}

Kata kunci : teater, tubuh, interogasi tubuh, ruang publik. 


\section{PENDAHULUAN}

Kegelisahan dalam sebuah proses panjang pada proses kreatif teater dari para pelakunya, aktor, sutradara atau penata artistik, dapat dijadikan sebagai modal dalam membuat sebuah kreativitas baru dalam penjelajahan prosesnya. Namun demikian, dalam merealisasikan kegelisahan ini tentu saja harus didukung dengan potensi-potensi kreatif lainnya dan disesuaikan dengan kebutuhan realitasnya sehingga mempunyai ciri khas dan warna tersendiri. Menurut Dedi Supriadi (1994: hal.7), kreativitas merupakan kemampuan seseorang untuk melahirkan sesuatu yang baru, baik berupa gagasan maupun karya nyata yang relatif berbeda dengan apa yang ada sebelumnya.

Kreativitas menjadi kunci bagi penulis dengan keyakinan bahwa kreativitas tidak dapat ditempuh dengan cara-cara instan. Hal itu dibuktikan oleh penulis dengan mengikuti proses kreatif selama kurang lebih 17 tahun pada kelompok teater Bandung (Teater Payung Hitam) yang dimulai dari tahun 1988 sampai dengan tahun 2005 sebagai pemain pada kelompok Teater Payung Hitam Bandung. Produksi Teater Payung Hitam sampai periode tahun 1990-an banyak menggunakan kata, sedangkan periode tahun 2000-an sampai sekarang lebih banyak mengeksplorasi tubuh. Sejak 2005 sampai sekarang penulis menjalani proses kreatif secara individu sebagai sutradara dan pemain, juga sebagai pengajar olah tubuh dasar aktor di Institut Seni Budaya Indonesia (ISBI) Bandung. Proses berkesenian berkelompok dan individu ini yang membuat penulis tergugah untuk mencoba menyikapi proses teater yang dijalani selama ini sebagai suatu tantangan yang harus disikapi dengan arif dan bijaksana. Situasi ini telah membangkitkan kegelisahan penulis yang berujung pada perenungan. Kegelisahan tersebut dituangkan ke dalam sebuah pencarian dari sebuah proses teater yang baru, yaitu menciptakan proses 'teater tubuh' untuk ditampilkan di ruang publik maupun juga panggung. Penulis melihat tubuh sebagai bahasa yang paling purba dan mempunyai kekuatan yang sangat luar biasa, sebagai salah satu bahasa non-verbal sebelum kata dilahirkan, seperti yang diungkapkan Herry Dim (2011: 156) :

"Dalam hubungan langsung atau pun tidak langsung, ihwal pengolahan "tubuh" sebagai bahasa utama teater mengalami pematangan pada sejumlah pementasan Teater Payung Hitam di tangan Rachman Sabur.Pucuk pencapaian "teater tubuh" dicapai oleh keberadaan Tony Broer yang sebelumnya tumbuh dikawah candradimukanya Teater Payung Hitam. Broer ketika memutuskan untuk "berdiri semata-matahanya dengan tubuhnya dan tubuh-tubuh lain yangsefaham," serta kemudian menjalani sejumlah pengalaman pertemuannya dengan Butoh, kian tegas memperlihatkan bahwa tubuh bisa menjadi segalanya; ia bisa menjadi 'wadah' biografis dari seseorang, flora, fauna, benda-benda, atau si pembawa tubuhnya secara langsung yang membawakan seluruh narasi, penentu ruang, dan menjadi wilayah artistik".

Penciptaan teater tubuh diartikan sebagai pemaknaan dari tubuh itu sendiri. Dimulai dari bahasa tubuh, lalu lahir kata, dan kembali pada tubuh yang sampai sekarang masih terus dieksplorasi menjadi media utama teater. Ini merupakan rangkaian proses kesadaran tentang "tubuh" yang harus dikonsepkan dengan bahasa verbal sehingga menjadi "Kata", tetapi masalah tubuh tidak pernah selesai dengan konsep, karena itu akan terus kembali pada "Tubuh".

Proses penciptaan teater tubuh merupa-kan penawaran pembaharuan teater dengan menggarap dan mengolah tubuh, yang menjadi kunci utama 
produksi teater. Tulisan ini menjadi upaya untuk menawarkan pikiran-pikiran baru dan pikiran-pikiran alternatif tentang teater tubuh yang berbeda. "TubuhKataTubuh' adalah judul dari proses latihan tubuh dengan kesadaran tubuh sebagai gagasan atau tubuh itu sendiri sebagai ide. Ini merupakan proses belajar pada tubuh sehingga mendapat kesadaran gerak-gerak yang dilahirkan oleh tubuh dan tidak ditempatkan tubuh sebagai alat untuk menyampaikan gagasan.

Proses latihan "TubuhKataTubuh' dilakukan dengan membongkar dan mempertanyakan kembali persoalan tubuh aktor, sebab tubuh aktor pada proses teater sekarang seperti sudah selesai pada tahap pementasan, maka tubuh aktor seharusnya dilatih kembali. Proses ini yang dinamakan sebagai proses 'interogasi tubuh', aktor selalu diingatkan pada tubuhnya. Proses latihan ini untuk menjawab persoalan tubuh-tubuh masyarakat hari ini yang sangat tergantung pada benda-benda yang ada di sekelilingnyadan tubuh masyarakat sekarang bisa dijadikan tema pada latihan interogasi tubuh. Proses interogasi tubuh aktor ini diharapkan bisa melahirkan tubuh baru pada tubuh masyarakat. Tubuh masyarakat yang ada di ruang-ruang publik dengan sebutan "tubuh gerombolan", tubuh yang tanpa disadari sangat tergantung pada benda-benda, dari kebutuhan yang khusus dan yang umum, seperti benda-benda untuk menyamankan tubuh, pakaian, sepatu, alat-alat rias, dan lainlain.

Proses latihan tubuh ini hanya mengeksplorasi tubuh, tidak mengeksplorasi kata yang dikeluarkan oleh aktor. Berbeda dengan Bengkel Teater yang juga pernah mengolah tubuh dalam rangka menciptakan bahasa tubuh tetapi pada kenyataannya digunakan juga sebagai pendamping bahasa verbal. Penciptaan teater tubuh menawarkan pandangan baru tentang tubuh yang bukan sekedar media ungkap tetapi tubuh itu sendiri mandiri sebagai sebuah identitas. Tubuh dipandang sebagai fenomena yang berdiri sendiri tetapi sekaligus melakukan relasi dengan lingkungan: jalan, bangunan, kendaraan, orang-orang dan bahkan seluruh masyarakat dan ideologinya yang sedang dominan pada saat itu. Dengan demikian, penciptaan teater tubuh adalah proses teater yang utuh antara aktor dan tubuh sekaligus relasinya dengan masyarakat.

Masyarakat kita semakin "wadhag" (fisikal). Tubuh menjadi komoditi bisnis, gincu, lipstik, rambut palsu, pembesar payudara, pewangi ketiak, dan lain-lain. Tubuh didudukkan pada posisi untuk menopang jiwa zaman (zeitgeist) karena terkait dengan benda-benda seperti mal, mobil, pakaian, tempat-tempat pelancongan, restoran mewah, dan sebagainya. Tubuh manusia sekarang dideterminasi oleh keadaan yang menentukan kuasa, sistem kapitalis, franchise, dan lain-lain. Bisnis semakin merebak, untuk memiliki motor atau mobil pun semakin mudah; museummuseum digusur untuk mal, anak-anak tidak mempunyai taman untuk bermain. Dalam konteks ruang anak ini, penulis melahirkan karya dengan judul "Ayah Mencari Taman", yang dipentaskan di sekitar jalan Dago Bandung tahun 2011. Pertunjukan jalanan ini mengisahkan tentang hilangnya ruang publik (taman) atau semakin sempit ruang tersebut, atau bahkan bisa dikatakan tidak ada sama sekali. Karya ini salah satu karya penulis di ruang publik.

Salah satu tujuan yang ingin dicapai dalam penciptaan karya teater tubuh ini adalah menciptakan kemungkinan ruang latihan untuk aktor. Menyadarkan pada aktor bahwa proses berlatih bukan karena 
ada target pementasan di panggung. Proses latihan ini juga menyadarkan aktor sebagai proses individu untuk melatih teknik tubuh dan juga penjiwaannya. Tubuh aktor yang dilatih melalui interogasi tubuhdiharapkan melahirkan meta-narasi tubuh di ruang publik, yang tidak sajaakan tampil di panggung, namun berbaur dengan tubuh publik dan berhadapan langsung dengan ruang publik.

Dalam bentuk yang lebih luas, proses interogasi tubuh menjadi "Ruang Aktor", yaitu sebuah ruang tempat berlatih aktor untuk menemukan "meta-narasi tubuh". Ini merupakan proses membongkar kembali gerak tubuh yang selama ini telah dilakukan oleh tubuh. Proses inidilakukan secara sadaruntuk melahirkan gerak tubuh baru denganmelatih kembali gerak yang telah dilahirkan oleh tubuh selama menjalani kehidupan dengan proses interogasi tubuh di ruang publik dan panggung. Tubuh aktor akan terlatih untuk bermain di ruang publik dan juga panggung.

Tubuh menjadi persoalan yang tidak pernah selesai dalam sebuah eksplorasi penciptaan teater untuk melahirkan seni pertunjukan tubuh. Dengan demikian, penulis merumuskan permasalahan sekaligus tujuannya dalam proses penciptaan teater tubuh, meliputi: 1) Bagaimana mewujudkan ide tubuh menjadi penciptaan teater tubuh?; 2) Bagaimana merancang penciptaan teater tubuh ?; 3) Bagaimana bentuk pementasan teater tubuh di ruang publik dan panggung?.

\section{METODE}

Penciptaan teater tubuh adalah karya dalam bentuk proses yang dirancang dalam latihan yang disebut interogasi tubuh aktor. Proses bagaimana tubuh aktor hadir di panggung atau ruang publik bukan sebagai media atau alat untuk menyampaikan suatu ide atau gagasan, tetapi tubuh adalah gagasan atau ide itu sendiri. Bagaimana tubuh aktor dibebaskan, menjadi mandiri, hadir dengan merdeka, sehingga tubuh itu sendiri menjadi peristiwa.

Proses karya penciptaan teater tubuh dilatihkan di ruang publik dan langsung dipertunjukkan pada ruang publiknya dengan penampilan artistik aktor yang berbeda. Sasaran pada proses penciptaan teater tubuh adalah langsung pada tubuh publik yang ada di jalan-jalan kota atau ruang tempat berkumpulnya tubuh sebagai bentuk penyadaran kembali eksistensi tubuh di ruang publik. Tubuh diperlihatkan dengan bentuk berbeda dengan tubuh publik, tetapi publik dapat menerimanya sebab secara penampilan tidak berbeda dengan mereka. Tubuh aktor akan melahirkan tubuh-tubuh tema yang dilatihkan dalam proses pembentukan tubuhnya. Tubuh tema ini yang akan menjadi katarsis pada tubuh yang melihat tubuhnya sendiri.

Pada tahap berikutnya masyarakat yang telah ditentukan bisa diikutsertakan dalam latihan-latihan dan hasil latihannya bisa ditampilkan untuk melahirkan meta-narasi tubuhnya di ruang mereka sendiri. Dalam hal proses "Ruang Aktor" disosialisasikan adanya proses atau metode interogasi tubuh aktor dengan mengadakan workshop tubuh untuk ruang publik dan panggung yang telah penulis lakukan di beberapa kota di Jawa dan di luar Jawa. Proses ini penulis lakukan sebagai upaya sosialisasi dari proses tubuh aktor. Selain menyosialisasikan, penulis juga mengamati proses interogasi tubuh aktor dan kegiatan workshopmelalui dokumentasi foto dan film, untuk dijadikan data dalam konsep penciptaan karya penciptaan teater tubuh. Lebih jelas, alur metode kerja penciptaan teater tubuh dapat dilihat pada gambar berikut. 


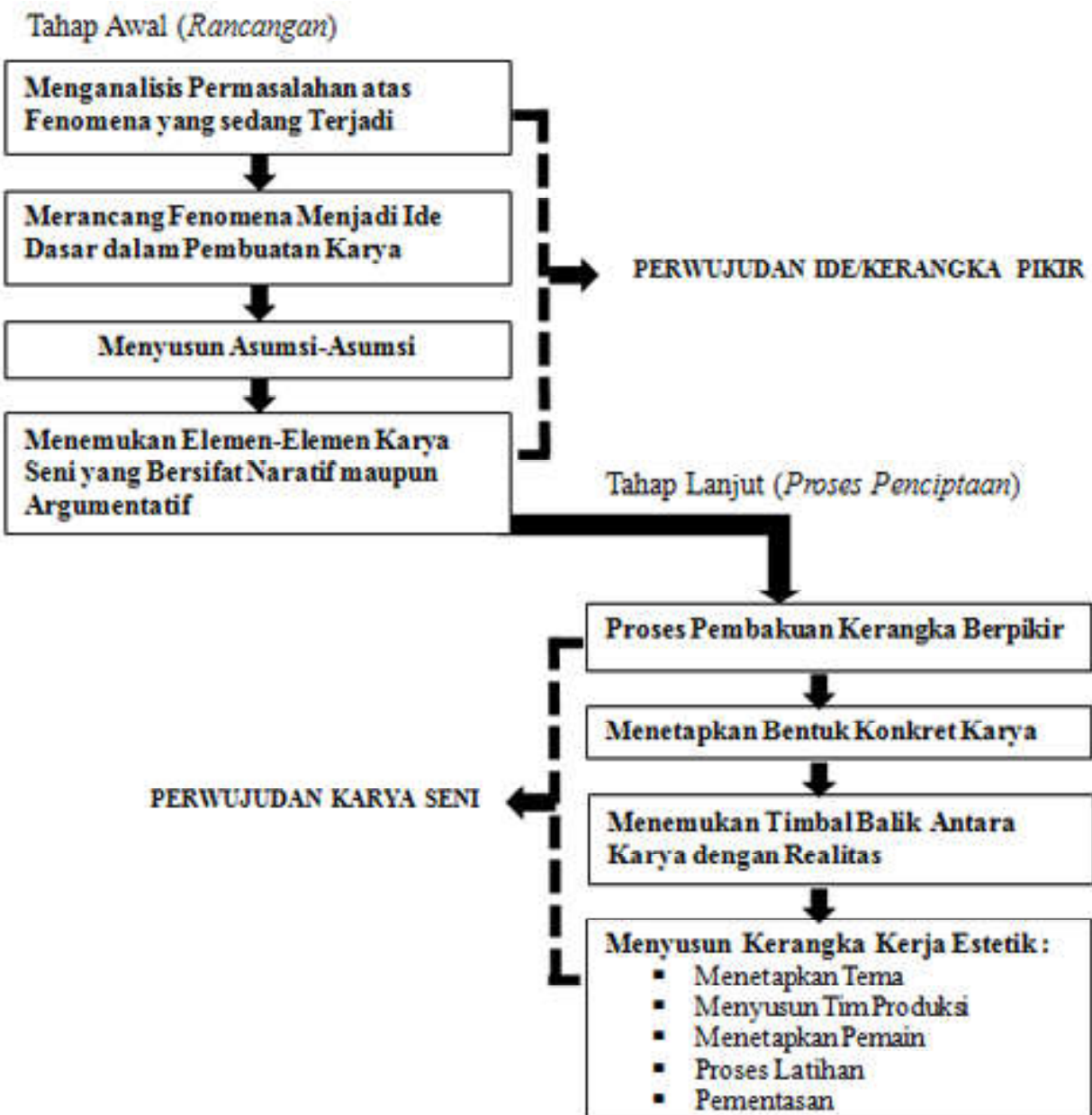

Gambar 1:

Alur Metode Penciptaan Teater Tubuh

\section{HASIL DAN PEMBAHASAN}

Pementasan teater yang dikomunikasikan pada publiknya adalah proses apresiasi antara karya dan publiknya yaitu proses komunikasi seni yang pasti akan terjadi sampai sekarang. Kehadiran teater dari proses penciptaan teater tubuh yang dirancang dalam tulisan ini tidak dapat menghindari hukum komunikasi, yakni ada stimulus dan respons. Adapun yang dimaksud dengan stimulus adalah ide, gagasan, yang disampaikan kepada publik. Untuk itu, ide butuh media. Dalam teater konvensional, tubuh adalah media penyampai ide. Tetapi dalam tulisan yang penulis buat, tubuh sebagai media didudukan sebagai ide atau gagasan.

\section{PerwujudanIde Tubuh Sebagai Penciptaan Teater Tubuh}

Pikiran tentang tubuh sebagai ide atau gagasan didukung oleh konsep yang diajukan oleh Marshal Mc. Luhan, "the media is the message" (1994: 7). Luhan mengatakan bahwa tubuh tidak lagi dilihat oleh publik sebagai alat atau media tapi tubuh itu sendiri oleh publik dilihat sebagai gagasan atau ide. Tubuh langsung menjadi pesan itu sendiri. Dalam proses penciptaan teater tubuh, publik atau penonton diberi kesadaran kembali pada tubuh yang selama ini dilupakan keberadaannya, seperti dalam mal atau tempat perbelanjaan yang mewah, maka ada kesepakatan tubuh yang tidak berpakaian layak atau kurang uang tidak ada 
keberanian masuk ke dalamnya. Tubuh diperdaya oleh benda-benda yang ada di sekitarnya, dan yang nampak adalah tubuh sebenarnya, yaitu tubuh-tubuh yang berkedok. Inilah tubuh masyarakat sekarang, dalam proses interogasi tubuh aktor ini akan dilatih sehingga bisa melahirkan metanarasi tubuh aktor. Penulis pada persoalan ini melihat tubuh menjadi sebuah persoalan, di mana teater harus kembali pada persoalan dasarnya, yaitu tubuh, seperti yang dikatakan olehJerzy Grotowski sebagai tokoh pembaharu dalam konsep teater, yaitu bahwa tubuh aktor menjadi media paling utama. Pada buku "Toward a Poor Theater" terjemahan Max Arifin, ia menyatakan bahwa tubuh aktor adalah inti dari teater itu sendiri. Penonton hanya melihat serangkaian denyut dari tubuh (ini yang disebut oleh konsep tubuh Grotowski dengan via negativa, tubuh bukan tumpukan keterampilan (skill) tetapi usaha menghilangkan semua penghalang (Grotowski, 2002: 5).

Penyerahan diri aktor secara total diwujudkan dalam teater miskin Grotowski. Di sinilah penulis menjadikan konsep tubuh dari Grotowski sebagai inspirasi dalam proses yang akan dilakukan dalam proses interogasi tubuh aktor yang akan membongkar meta-narasi tubuh aktor. Tubuh menjadi media utama dan menjadi inti dari penciptaan teater tubuh yang dapat dimainkan di panggung dan di ruang publik. Grotowski (2002: 13) menyatakan sang aktor lahir kembali bukan saja sebagai seorang aktor tetapi sebagai seseorang, dan dengan dia saya lahir kembali. Grotowski menempatkan inti pada peristiwa teater adalah aktor. Tulisan ini mengajukan rancangan aktor hadir bukan karena kostum dan make-up, tetapi karena tubuhnya. Penemuan ini tetap berpijak pada keutuhan "tubuh" aktor, yaitu tubuh yang merupakan media penghubung partisipasi baik dari sudut keaktoran mupun penonton (Yudiaryani, 2002: xiii).

Seni pertunjukan (performance art) adalah karya seni yang melibatkan aksi individu atau kelompok di tempat dan waktu tertentu. Seni pertunjukan ini biasanya melibatkan empat unsur: waktu, ruang, tubuh seniman, dan hubungan seniman dengan penonton. Dalam masyarakat baru atau modern, seni pertunjukan adalah kegiatan di luar kegiatan kerja seharihari (Sumardjo, dkk., 2001: 2). Meskipun seni pertunjukan bisa juga dikatakan termasuk di dalamnya kegiatan-kegiatan seni mainstream seperti teater, tari, musik, dan sirkus, tetapi biasanya kegiatan-kegiatan seni tersebut pada umumnya lebih dikenal dengan istilah seni pertunjukan.

Berangkat dari penjelasan di atas, Butoh dan Geikidan Kaitaisha penulis jadikan inspirasi dalam mencipta metode pelatihan Interogasi Tubuh. Butoh dan Geikidan Kaitashaadalah proses penyikapan persoalan manusia sampai saat sekarang. Hal ini sebagai suatu tantangan yang harus disikapi dengan arif dan bijaksana. Penyikapan Butoh dan Geikidan Kaitasha ini dituangkan ke dalam sebuah pencarian dari sebuah proses teater yang baru. Karya teater ini adalah teater yang karyanya dapat dipentaskan di jalanan dan di dalam gedung pertunjukan. Butoh dan Geikidan Kaitaisha menggunakan tubuh sebagai media ungkapnya. Penulis sebelumnya pernah terlibat secara langsung dalam latihanlatihan Butoh dengan Kazuo Ohno, dan ikut serta dalam pelatihan dan produksi kolaborasi internasional dengan kelompok Geikidan Kaitaisha.

Fenomena penggunaan media tubuh sebagai penyampai ide dan gagasan kepada apresiator juga terdapat pada beberapa kelompok teater di Indonesia. Seperti 
beberapa pementasan Teater Garasi, Teater Kubur dan Teater Payung Hitam. Proses kreatif dan teknik yang digunakan oleh masing-masing kelompok teater ini memang berbeda, tetapi semangat untuk membongkar tubuh sebagai gagasan, juga eksplorasi tubuh yang dilakukan masingmasing kelompok, menjadi pembanding dalam mencipta metode pelatihan ini, karena penulis pernah ikut serta sebagai pemain (Teater Payung Hitam) dan penonton (Teater Garasi dan Teater Kubur).

Dalam Damajanti (2006: 12; 21) dijelaskan bahwa kreativitas adalah alat utama untuk mengembangkan inovasi yang sering diasosiasikan dengan aktivitas artistik. Kreativitas berarti menciptakan atau membuat sesuatu yang berbeda (bentuk, susunan, dan gayanya) dengan yang lazim dikenal orang banyak. Perbedaan yang diciptakan atau yang dibuat itu sekaligus merupakan pembaharuan tanpa atau dengan mengubah fungsi pokok dari sesuatu yang diciptakan itu. Setiap aktivitas yang menyangkut pengkodean makna dimulai dengan kerja eksperimen dan penjelasan yang intensif. Gunanya, untuk menemukan berbagai kemungkinan artistik sekaligus estetis dalam penciptaan karya. Penemuan dari serangkaian kerja tersebut kemudian dikodifikasi dan dirajut untuk menjadi suatu karya seni yang total (utuh).

\section{Metode Penciptaan Teater Tubuh Sebagai Penyatuan Tubuh Aktor dan Masyarakat}

Tubuh masyarakat adalah tubuh sekarang, menjadi sebuah pilihan untuk terus dibongkar, sehingga akan melahirkan proses karya ini pada tubuh aktor dan masyarakat yang diikutsertakan. Di ruang publik akan muncul bahasa tubuh baru yang disadari maupun tidak disadari oleh aktor dan juga oleh publik sebagai tubuh gerombolan yang ada di ruang publik.
"Interogasi Tubuh" adalah proses latihan tubuh aktor dalam karya penciptaan teater tubuh sebagai bahan dasar yang dipakai untuk melahirkan proses teater yang baru.

Tubuh yang bebas sebenarnya tidak bebas. Kebebasan itu sendiri juga terikat. Teater tubuh adalah teater verbal dan konvensional bila bahasa dan seluruh idiomnya pada suatu saat mulai mapan. Teater bukan hanya pertunjukan yang bertutur dengan bahasa yang dikenal sebagai drama, tetapi juga pertunjukan yang ber-"bahasa" dengan tubuh, rupa dan bunyi (Putu Wijaya, 2008: 23). Tubuh sebagai proses dialog menjadi sebuah eksplorasi yang tidak pernah selesai dari kelompok teater yang memilih proses ini. Dalam pertunjukan hampir tidak ada dialog yang keluar dari mulut aktor, kalau pun ada hanya sebagai hasil dan akibat dari ekspresi tubuh. Kekuatan tubuh, kelenturan tubuh, dan keseimbangan tubuh menjadi dasar-dasar latihan yang dipakai oleh kelompok teater yang memilih tubuh sebagai proses dialog. Tubuh bukan alat penyampai dialog naskah, sehingga tubuh menjadi tujuan itu sendiri yang di dalamnya ada plot, karakter, konflik, struktur, irama bahkan pernyataanpernyataan, maka proses tubuh ini akan menemukan "bahasa" tubuh tersendiri.

Metode latihan tubuh Butoh diterapkan dalam proses latihan "Interogasi Tubuh" yang ada dalam penciptaan teater tubuh. Tokoh yang pertama kali memperkenalkan Butoh adalah Kazuo Ohno dan Tatsumi Hijikata. Butoh adalah sebuah eksplorasi tubuh yang lahir di Jepang sekitar tahun 60an. Gerakan kesenian ini menjadi pelopor dari munculnya semangat eksplorasi pada tubuh. Butoh tidak menjadi sebuah tarian yang baku, namun menjadi bentuk seni pertunjukan yang baru pada waktu itu. Sekitar tahun 70-an Butoh mulai dikenal di 
luar Jepang dan sampai sekarang menjadi metode eksplorasi tubuh dan digunakan sebagai dasar latihan kelompok teater yang memilih bentuk tubuh sebagai media ekspresi. Selain Butoh, penulis memakai metode Geikidan Kaitaisha yang dikenal dengan "Theatre of Deconstruction", teater yang mendekonstruksi kembali tubuh, menjadi pernyataan global untuk melawan globalisasi, sebuah sikap perlawanan dengan tidak menyerang tetapi masuk ke dalamnya. Pementasan Geikidan Kaitaisha yang memakai tubuh sebagai konsep teaternya, menemukan latihan-latihan tubuh dari eksplorasi-eksplorasi dalam setiap latihan, yang dijadikan konsep teater tubuh Geikidan Kaitaisha.

"Interogasi Tubuh" dalam prosesnya memakai acuan dari konsep latihan tubuh Butoh dan Gekidan Kaitaisha. Dalam "Interogasi Tubuh" diolah kembali sesuai dengan yang ditemukan oleh penulis selama melatih konsep tubuh ini. Butoh dan Gekidan Kaitaisha mempunyai kesamaan dalam konsep tubuhnya yaitu memakai tubuh bukan sebagai alat atau media untuk menyampaikan gagasan atau ide, tapi tubuh sebagai gagasan atau ide itu sendiri, walaupun keduanya mempunyai perbedaan dalam proses latihannya. Proses terusmenerus melatih tubuh untuk terus memberikan kesadaran pada aktor bahwa tubuhnya sendiri adalah gagasan atau ide, dengan membongkar tubuh untuk menemukan meta-narasi tubuh aktor. Penulis juga melengkapi proses latihan tubuh ini dengan proses yang selama ini dilakukan dalam proses mencipta karyakarya tubuhnya sejak tahun 2005 sampai sekarang.

Perkembangan teater tubuh berbeda dengan dunia tari yang juga paling dekat dengan tubuh. Proses penciptaan tari yang jelas menggunakan tubuh sebagai media penyampai gagasan, kesenian yang menggunakan tubuhnya sendiri sebagai medianya. Menjadi sangat tidak masuk akal kalau begitu saja membiarkan tubuhnya diambil oleh wacana lain. Tubuh adalah alasan pertama manusia memasuki bahasabahasa kesenian; ketika bahasa yang dimasukinya itu merupakan perangkap sistem nilai yang akan menguasainya, maka pada saat itu tari sudah mati (Malna, 2008: 21). Tubuh menjadi sebuah sumber yang tidak akan pernah selesai untuk dieksplorasi dalam dunia teater, maka tubuh adalah sebuah kebebasan, bahasa-bahasa tubuh yang baru akan terus dilahirkan pada tubuh aktor.

Menurut Damajanti (2006: 61), dalam proses penciptaan karya seni seniman terusmenerus dihadapkan pada masalah yang harus dipecahkan. Proses "Interogasi tubuh" dilakukan dalam latihan tubuh pada penciptaan teater tubuh untuk membongkar meta-narasi tubuh yang akan dihadirkan di ruang publik juga di panggung. Penciptaan teater tubuh adalah sebuah program khusus pementasan teater berupa pertunjukan di ruang publik yang menjadi tempat berkumpulnya tubuhtubuh, seperti di halte, taman kota, stasiun bus, mal atau pusat perbelanjaan, jalan raya, dan lain-lain. Pertunjukan yang mengambil ruang publik sebagai panggung pertunjukan, sekaligus untuk melihat secara langsung respons dari masyarakat yang menyaksikan ketika tubuh-tubuh kembali dihadirkan kepada mereka. Interogasi di ruang publik, akhirnya akan menciptakan komunikasi yang jujur antara aktor dan apresiatornya.

Tubuh sekarang sebagai objek dari pertunjukan yang tentu akan memberikan respons alami dari apa yang disajikan dalam pertunjukan. Hal inilah yang akhirnya mengungkap pernyataan tentang konflik 
tersembunyi pada tubuh yang mungkin tidak disadari. Logika dan pola yang mereka terima dan terapkan sekaligus selama ini, akan kembali diusik untuk dipertanyakan oleh mereka sendiri. Cara ini ditempuh sebagai upaya untuk "mengganggu" konstruksi nalar mereka yang sudah tertanam dan disepakati bersama, untuk "menyingkap" identitas dan realitas yang disembunyikan. Proses ini diciptakan untuk menimbulkan daya tarik epistemik dan estetik sekaligus. Proses selanjutnya dibuat perencanaan produksi yang akan dipakai sebagai acuan program kerja dalam proses penciptaannya.

Proses penciptaan teater tubuh merupakan perjalanan proses kreatif dari seniman atau pelaku teater itu sendiri, baik sebagai sutradara atau aktor. Perjalanan dari proses kreatif ini yang kemudian dituliskan dalam sebuah proses penciptaan teater tubuh yang berisi proses latihan untuk melahirkan pentas teater baru, baik tubuh di ruang publik maupun tubuh di panggung. Proses selanjutnya adalah aktor melakukan latihanlatihan yang ada di dalam penciptaan teater tubuh. Tahapan selanjutnya adalah aktor mementaskannya sesuai dengan hasil proses latihannya. Proses pementasan ini adalah sebuah proses penyampaian ide kreasi aktor kepada publik yang ada di ruang publik, sehingga publik dapat membaca proses kreatif dari aktor tersebut. Pementasan karya tubuh di ruang publik dan panggung ini hasil dari proses penciptaan teater tubuh. Pementasan ini diwujudkan dengan harapan untuk dapat menambah keragaman dan menawarkan alternatif dalam proses eksplorasi tubuh yang ada dalam proses kreatif dunia teater. Kesadaran bahwa eksplorasi tubuh teater tidak akan pernah selesai dan selalu memberi inspirasi dalam proses kreatif penciptaan teater, menjadikannya sangat penting dalam proses eksplorasi pencarian metode ketubuhan. Di sini terlihat semangat dari sebuah proses pencarian yang tidak pernah selesai, sehingga proses kreatif melahirkan metode dan karya yang lebih bermakna langsung pada publik. Kesadaran pada proses kreatif menjadi semangat pencarian pada pelaku teater itu sendiri untuk melahirkan kebaruan dalam penciptaan teater.

Tubuh menjadi pilihan penulis secara total sebagai ide dasar dalam proses penciptaan teater tubuh, di mana dalam proses kreatif teater tubuh, sampai hari ini menjadi ide yang tidak pernah selesai. Fenomena teater tubuh sampai sekarang menjadi proses eksplorasi yang menarik yang dilakukan oleh kelompok-kelompok teater, aktor, dan bersamaan dengan fenomena masyarakat. Kebersamaan menjadi bentuk penyatuan antara pelaku seni dan masyarakat dalam proses penciptaan teater tubuh yang diyakini menjadi bentukbentuk baru proses penciptaandalam teater.

\section{Bentuk Teater Tubuh Di Ruang Publik dan Jalan}

Peristiwa yang diangkat dalam proses penciptaan teater tubuh adalah fenomena yang terjadi di jalan raya dan ruang publik. Kedua tempat ini adalah tempat bertemunya beragam kepentingan dan aktifitas masyarakat. Prosesnya sendiri menghadirkan kembali permasalahanpermasalahan yang dihadapi masyarakat secara umum agar tercipta komunikasiestetik (Jaeni, 2012) antara pertunjukan dan masyarakat yang menyaksikannya. Komunikasi tersebut merupakan relasi nilainilai yang dapat memberi kesempatan bagi masyarakat untuk berpartisipasi sekaligus memberi tanggapan terhadap pertunjukan yang disaksikannya.

Bentuk teater tubuh yang diwujudkan penulis bisa menjadi cara baru, namun 
dalam proses penciptaannya dikawal oleh pemikiran teater lingkungan Richard Schechner dan teater jalanan (Theatre of Road) seperti dijelaskan berikut ini.

\section{Konsep Pemikiran Richard Schechner}

Schechner menggunakan tiga model yaitu fan,web, dan infinity loop dalam membahas perfomance. Model kipas angin (fan) disajikan sebagai spektrum pengorganisasian kategori, dan model jaringan (web) disajikan untuk mengungkapkan pengaruh dinamis dan interkoneksinya. Model ketiga dari Schechner adalah diagram "lingkaran tak terbatas" (infinity loop) yang menjelaskan relasi antara drama sosial dan drama estetik. Model ini akan digunakan sebagai referensi teori dalam penulisan proses penciptaan teater tubuh. Berikut adalah gambar dari diagram "lingkaran tak terbatas"

Schechner membahas drama sosial, dan meminjam diagram dari Victor Turner untuk mengintegrasikan antara drama dan estetika. Diagram ini menggambarkan umpan balik positif yang dinamis, bahwa drama sosial mempengaruhi drama estetik, drama estetik mempengaruhi drama sosial (Schechner, 2004:214). Dengan kata lain, relasi antara drama sosial dan drama estetik adalah ulang-alik. Keduanya saling mempengaruhi untuk mempertahankan konsistensi masing-masing. Jika drama estetis menggunakan drama sosial -yang termanifestasi dalam peristiwa sosial dan politik - sebagai sumber penciptaannya, maka drama sosial memiliki kecenderungan untuk menggunakan drama estetis sebagai metode penulisannya di atas panggung.

Dalam proses penciptaan bentuk teater tubuh, penulis menggunakan teori teater lingkungan dari Richard Schechner yang erat hubungannya dengan model "lingkaran tak terbatas" (infinity loop). Teater lingkungan merupakan tekstur teater yang dirajut dari teks lingkungannya. Lingkungan secara teatrikal dapat dipahami dengan dua cara, pertama, seseorang dapat bekerja dalam suatu lingkungan, dalam arti ia mencipta lingkungan dengan mengubah ruang; kedua, seseorang menyetujui saja bekerja dalam lingkungan yang ada, dalam arti melakukan negosiasi dengan lingkungan dan berdialog dengan ruang.

Dengan demikian, peristiwa teatrikal pada teater tubuh dapat berlangsung baik dalam ruang yang secara total telah diubah formatnya, atau ruang yang ditemukan

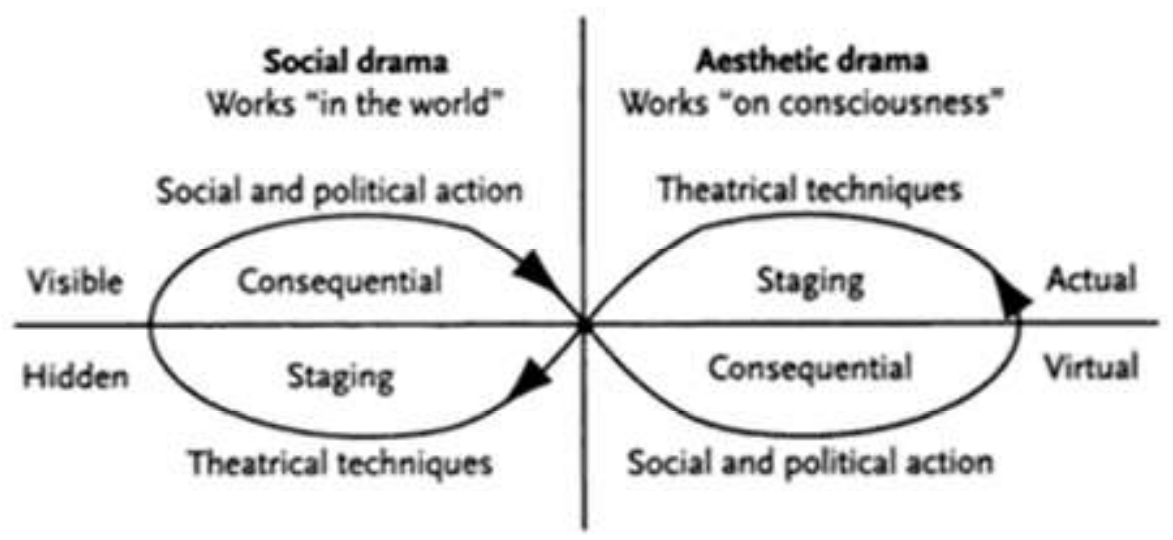

Gambar 2:

Diagram “lingkarantakterbatas” (Schechner, 2004: 214). 
secara spontan. Konsep teater demikian berfungsi untuk menyerap potensi-potensi yang ada di alam sekitar untuk memperkaya unsur-unsur pertunjukan (Yudiaryani, 2002: 323-324). Artinya, bahwa teater berasal dari jaringan lingkungan yang melibatkan peristiwa yang terjadi dalam masyarakat.

Sebagai tekstur, teater tubuh membentuk jaringan dari peristiwa tersebut dan dikomunikasikan kepada penonton. Penonton diharapkan berpartisipasi dengan memberi tanggapan terhadap pertunjukan teater. Tanggapan tersebut juga merupakan bagian dari tekstur. Partisipasi penonton terhadap pemaknaan pertunjukan teater lingkungan menghadirkan teater sebagai representasi peristiwa sosial. Sementara, teater tubuh membuat jaringan teks, baik yang berbentuk horizontal (dengan peristiwa seni) maupun vertikal (dengan peristiwa non-seni, seperti sosial, politik, dan budaya). Hal-hal demikian yang menginspirasi teater tubuh yang penulis ciptakan, sebagai jenis teater yang melibatkan aktivitas manusia sebagai suatu jaringan yang menyatukan seluruh peristiwa, baik horisontal maupun vertikal. Seniman terlibat dengan masalah sosial yang secara integral terkait pula dengan karyanya. Dalam pandangan ini, seniman akan menerjemahkan keinginannya ke dalam tindak pembacaan sosial yang dihadirkan melalui pertunjukan teater.

\section{Konsep Pemikiran Teater Jalanan}

Beragamnya kepentingan masyarakat yang bertemu di sebuah ruang publik, menjadi tantangan bagi penulis demi keberhasilan komunikasi untuk memecahkan misteri yang akan ditemui pertunjukan ini karena segala sesuatu yang terjadi tidak dapat diprediksi. Seperti yang dikatakan Judith Malina dalam wawancara dengan Cindy Rosenthal (dalam Cohen \&
Cruz, 1998: 50) bahwa jalan raya adalah sebuah tempat yang penuh misteri karena merupakan milik semua orang yang menjadi lorong menuju ke tempat lain di mana orang tidak ingin berhenti. Jalan memiliki aturan sendiri yang berbeda dari setiap jalan yang lainnya, sebagaimana satu orang berbeda dengan orang lain. Estetika teater jalanan didasarkan pada usaha untuk memahami bahasa orang-orang yang berada di jalan tersebut.

Penulis menyadari dalam proses penciptaan teater tubuh yang dipertunjukkan di ruang publik akan menghadapi apa yang disebut dengan estetika jalanan, yaitu belajar memahami bahasa tubuh yang ada di jalanan. Hal ini disebabkan karena tubuh menjadi poin yang sangat dominan dalam penciptaan teater tubuh untuk membongkar kesadaran pada bahasa tubuh yang harus terus dicari dalam latihan interogasi tubuh aktor.

Ruang publik adalah ranah-ranah kehidupan bersama yang diperebutkan dalam arus peristiwa sehari-hari, tergantung pada kekuatan yang punya sumber daya yang paling kuat untuk menguasainya (Herry \& Priyono dalam Hardiman, 2010: 370). Tubuh menjadi hilang dalam ruang publik sebab yang terjadi adalah ruang transaksi benda-benda yang selalu ingin dimiliki oleh tubuh, kendaraan roda dua, dan lain-lain. Handphone adalah salah satu contoh benda yang disadari atau tidak disadari membentuk tubuh gerombolan di jalan raya, yang sebenarnya mempunyai fungsi sosialnya untuk perjalanan jauh menjadi lebih dekat dan lebih cepat; dan ketika komunikasi sosial dengan alat komunikasi - handphone - tak disadari terbentuklah tubuh autis - tubuh sangat dikuasai benda - semua menjadi pendek dalam hal komunikasi, tubuh menjadi diam tak bergerak. 

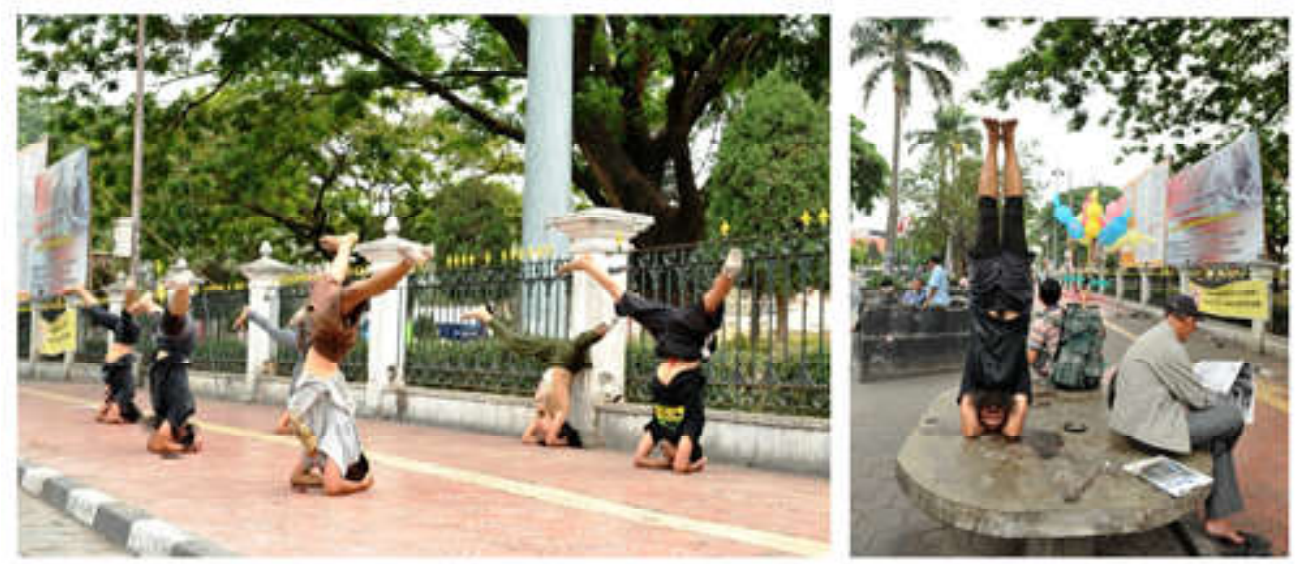

Gambar 3:

Proses latihan "Interogasi Tubuh" di ruang publik

(Foto: Yuyun Trimulyana, tahun 2012)

Pemilihan ruang publik dan ruang terbuka sebagai tempat pertunjukan teater tubuh, Mason (1992: 85-86) menjelaskan bahwa pada pertunjukan di luar ruangan, perubahan kondisi dan gangguan di setiap pertunjukan adalah peristiwa unik, menuntut pemain untuk memiliki semangat dan energi yang besar dan kemungkinan untuk menggunakan materi, lokasi, dan efek yang berbeda, karena sebaliknya pertunjukan di dalam ruangan cenderung menjadi lebih dari sebuah produk yang mudah diulang. Pengulangan memberi kesempatan untuk penataan tetapi sekaligus juga kurang memberikan fleksibilitas. Penulis dalam proses penciptaan teater tubuh pada pementasan di ruang publik dan di dalam gedung mengalami peristiwa unik dan proses kreatif dari pemain yang berbeda, sedangkan untuk proses di dalam gedung masuk pada proses pengulangan dari adegan-adegan yang dibuat.

Madison (dalam Denzin, 2011: 590) menambahkan bahwa pertunjukan jalanan merupakan gambaran lain fungsi komunikatif dan efektivitas politis per-tunjukan dalam menggerakkan komunitas menuju perubahan. Penulis yakin bahwa fungsi komunikatif yang terjadi pada pementasan di ruang publik dan panggung akan mengalami perbedaan, di ruang publik sebuah perubahan bisa ditawarkan langsung pada publiknya yang sebenarnya berbeda dengan publik yang memang siap menonton pementasan dalam gedung.

\section{SIMPULAN}

Pemikiran teater jalanan merupakan sebuah proses yang terus akan berkembang bahkan mungkin akan berubah sebab pemikiran yang ada dalam konsep teater jalanan adalah fenomena dari proses penciptaan teater di luar panggung atau di dalam panggung. Keterlibatan kreator dalam proses penciptaan teater tubuh mutlak adanya sebagai bagian dari proses latihan interogasi tubuh aktor. Proses interogasi tubuh aktoriniakan mendapatkan konsep karya seni. Proses penciptaan teater tubuh tidak bisa dalam waktu singkat, namun memerlukan waktu proses yang panjang karena harus trial and error, mencoba lalu gagal, kembali mencoba lalu gagal lagi, dan terus dilakukan proses ini hingga menjadi konsep dasar dari latihan interogasi tubuh aktor. Proses latihan panjang ini yang menjadi poin sangat penting dan harus disadari oleh aktor untuk menumbuhkan ide, gagasan, pikiran, dan kerangka perwujudan estetik. 
Aktor dalam melakukan latihan interogasi tubuh akan menjalani tiga tahap proses yaitu, proses tubuh fisik, aktor menjalani proses fisik, proses tubuh tema, aktor mulai masuk pada latihan tubuh yang berkomunikasi dengan benda-benda di luar tubuhnya, atau yang ada di sekitarnya, termasuk tubuh-tubuh yang ada di sekitarnya, dan proses tubuh aplikasi, aktor dinyatakan sudah siap untuk melahirkan tubuhnya di jalan atau di panggung.

Proses selanjutnya adalah pertunjukan di ruang publik sebagai sebuah eksperimen. Pentas teater ini di mal, di jalanjalan, di alun-alun, di depan toko, di pasarpasar, atau di mana saja. Pentas bisa menarik orang banyak atau justru tidak menarik sama sekali. Bahkan bisa dianggap pertunjukan ini dilakukan oleh seorang yang gila. Reaksi orang-orang jalanan itu akan diamati dan direkam dengan kamera. Hasil rekaman itu akan menampakkan sebuah fenomena dialog publik dengan tubuh. Apakah orang-orang jalanan "menjadi" sadar, bahwa tubuh aktor itu bisa juga tubuh mereka sendiri? Aktor yang bermain di jalan-jalan umum bisa menjadi stimulus bagi publik bahwa mereka melihat diri mereka sendiri. Apa yang lebih diharapkan adalah, bahwa publik bisa menyaksikan bahwa tubuh bisa tegar, kuat, atau lemah dan putus asa bahkan tersiksa.

Setelah pementasan, proses untuk mempelajari dan mendiskusikan kembali teater tubuh dilakukan agar dapat mencatatkan meta-narasi yang dimunculkan oleh tubuh aktor di ruang publik. Ini bagian dari kerja evaluasi yang sangat penting untuk dijadikan masukan bagi aktor ketika kembali melakukan proses latihan pada tahap interogasi tubuh.
Daftar Pustaka

Afrizal Malna

2008 "Konflik Tubuh-Kolonial dan Tubuh Post-Kolonial, Erotika dan Raga". Majalah GONG Edisi 102/IX.

Budi Hardiman, F. (editor).

2010 Ruang Publik, Melacak "Partisipasi Demokratis" dari Polis sampai Cyberspace. Yogyakarta: Penerbit Kanisius

Cohen, Jan \& Cruz, (editor).

1998 Radical Sreet Performance, an International Anthology. London and New York: Routledge.

Dedi Supriadi

1994 Kreativitas, Kebudayaan dan Perkembangan Iptek. Bandung: Alvabeta

Denzin, K. Norman \& Yvonna S. Lincoln, (editor).

2011 The Sage Handbook of Qualitative Research 1. Yogyakarta: Pustaka Pelajar.

Jaeni

2012 “Komunikasi Estetik dalam Seni PertunjukanTeater Rakyat Sandiwara Cirebon", Jurnal Panggung: Signifikasi Makna Seni dalam Berbagai Dimensi, Vol 22, no. 2, p 160-168), STSI Bandung.

Herry Dim

2011 Badingkut: Di antara Tiga Jalan Teater. Depok: Penerbit Komodo Books.

Irma Damajanti

2006 Psikologi Seni. Bandung: Kiblat Buku Utama.

Jakob Sumardjo, dkk.

2001 Seni Pertunjukan Indonesia, Suatu Pendekatan Sejarah. Bandung: STSI Press.

Luhan, Marshal Mc.

1994 Understanding Media. London, Massachusetts: MIT Press Cambridge.

Mason, Bim.

1992 Street Theatre and Other Outdoor Performance. London and New York: Routledge. 
Jerzy Grotowski Yudiaryani

2002 Mепијu Teater Miskin, 2002 Panggung Teater Dunia: (Diterjemahkan oleh Max Arifin). Perkembangan Konvensi dan Bentuk Yogyakarta: MSPI \& Arti. Teater. Yogyakarta: Pustaka Gondho

Putu Wijaya Suli.

2008 Teater Tubuh, Erotika dan Raga. Majalah GONG Edisi 102/IX.

Schechner, Richard

2004 Performance Theory. London and New York: Routledge. 